\title{
Editorial: a short history of the climate change litigation boom across Europe
}

\author{
Kleoniki Pouikli ${ }^{1}$
}

Accepted: 24 January 2022 / Published online: 15 February 2022 (c) @ ERA 2022

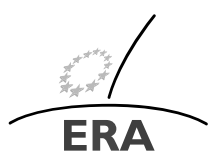

EUROPÄISCHE RECHTSAKADEMIE ACADEMY OF EUROPEAN LAW ACADEMIE DE DROIT EUROPEEN ACCADEMIA DI DIRITTO EUROPEO

\begin{abstract}
The aim of this paper is to map the most significant milestones in the emergence and development of climate change litigation in Europe. The climate crisis has arrived at the epicentre of the global political agenda and the EU aspires to have a leading role in the efforts to deal with global warming. Along with EU climate action, the number of climate-related court cases on the European landscape, both at regional and domestic level, is constantly on the increase. In this context, this paper unpacks the main elements of the landmark climate rulings across Europe as well as the key challenges relating to climate litigation.
\end{abstract}

Keywords Climate change $\cdot$ Climate litigation $\cdot$ Human rights $\cdot$ National courts

\section{Introduction}

Climate crisis has emerged as an increasingly salient issue on the global political agenda in the wake of the first assessment report of the Intergovernmental Panel on Climate Change (hereinafter: IPCC) published in 1990. Almost thirty years later, the 2018 special report by the IPCC "Global Warming of 1.5 Degrees" has very bluntly displayed the unprecedented dimensions of climate change, not only in scope, but also in scale, time, and space, by showing that if global warming exceeds 1.5 degrees Centigrade, the consequences will be deeply disruptive for human systems (economic, social and even legal), as well as for ecosystems and

Dr K. Pouikli

KPouikli@era.int

1 Deputy Head of Section (EU Public Law), Academy of European Law, Trier, Germany 
species. ${ }^{1}$ Despite the intense political efforts made in the last three decades ${ }^{2}$ and scientifically-informed warnings of the irreversible and likely catastrophic effects of anthropogenic $\mathrm{CO}_{2}$ releases and the continuous rise of global temperatures, global climate action so far appears to be insufficient, given that climate crisis remains "the defining challenge of our time having led to dramatic alterations in our planet's climate system". 3 A recent joint research project addressed this challenging question and-by reviewing three decades of climate change mitigation through the lens of ninethematic areas - identified a cluster of reasons for ineffective mitigation efforts, such as the failure of leadership particularly from within high-emitting countries, sectors and corporations, the status quo of the geopolitical, industrial and military interests and balances, the entrenched toolbox in the fields of economics, energy and climate science. $^{4}$

According to scientists, in view of all the time wasted, it is imperative that a fundamental, system-wide reorganisation involving technological, economic and social factors occur within the next 10-15 years in order to reduce greenhouse gas emissions to net-zero by around 2050 and get to negative emissions thereafter. ${ }^{5}$ The urgent need for transformative changes has been recently supported by a wide-spread phenomenon of climate change litigation: namely, that citizens individually or in groups and/or associations have questioned the effectiveness and appropriateness of the efforts made on behalf of governments and companies to tackle climate change and challenged their climate (in)action before courts. Hence, courts have emerged as a crucial lever in this necessary transformation.

Climate change litigation refers to a heterogeneous and diverse group of climate change-related cases before courts as well as regulatory bodies and their tribunals. More specifically, there are cases seeking accountability, others aiming at damage reparation and others focusing on testing legal tools in the courtroom for the achievement of the $1.5^{\circ} \mathrm{C}$ objective. Nevertheless, the overarching rationale underlying climate cases is that courts can assume the rightful role in holding governments and companies accountable for their insufficient action on the climate challenge and, by extension, offsetting the missing political will and engagement as well as the lack of effective enforcement of the existing climate provisions.

The number of climate-related cases at European landscape, identified both at regional and domestic level, is steadily rising. ${ }^{6}$ Given that the focus of this paper is to map the wide array of climate cases before national courts, only a few thoughts on

\footnotetext{
${ }^{1}$ IPCC, Global warming of $1.5{ }^{\circ} \mathrm{C}$ : An IPCC Special Report on the impacts of global warming of 1.5 ${ }^{\circ} \mathrm{C}$ above pre-industrial levels and the related global greenhouse gas emission pathways, in the context of strengthening the global response to the threat of climate change, sustainable development, and efforts to eradicate poverty (October 2018). Summary for Policymakers, p. 32 (IPCC, 2018).

${ }^{2}$ The United Nations Framework Convention on Climate Change (UNFCCC) in 1992, the Kyoto Protocol in 1997 and the Paris Agreement in 2015.

${ }^{3}$ Lahore High Court, Order of 4 September 2015, W.P. No. 25501/2015, Ashgar v. Federation of Pakistan.

${ }^{4}$ Stoddard [25], pp. 653-689.

${ }^{5}$ IPCC 2018.

${ }^{6}$ For an overview of climate cases, see the database maintained by the Grantham research Institute on Climate Change and the Environment. Available at: Climate Change Laws of the World (climate-laws. org).
} 
climate change litigation before regional courts in Europe will be briefly expressed at this point. Regarding the courts of the EU, the stringent locus standi requirements enshrined in Article 263 TFEU have proved to be an insurmountable barrier for private parties to challenge EU legislative acts on climate-related issues. As demonstrated both in the People's Climate case ${ }^{7}$ and the EU Biomass case, ${ }^{8}$ where the applicants sought judicial review of the EU's legislative acts, ${ }^{9}$ the admissibility of these applications hit the admissibility "wall" of Article 263(4) TFEU ${ }^{10}$ based on the famous Plaumann case in 1963, which has been heavily criticised by the legal theory and has raised significant concerns regarding its compatibility with the Aarhus Convention. ${ }^{11}$

To overcome the Plaumann test, the applicants in these two climate cases argued that any violation of human rights was by its very nature unique or, in the alternative, that the test should be altered to take account of the reality of climate change. ${ }^{12}$ However, the CJEU has shown no intention of revisiting or abandoning the Plaumann formula notwithstanding the fact that its effect is to defuse the human rights arsenal. As bluntly stated by Ludwig Krämer,

"the Court of Justice will commit an intellectual error, if it continues to rely on the Plaumann formula in cases, where several persons are affected as regards their human rights and when it declares that in such cases, an applicant is not individually concerned in his human rights, because there are other persons in the same situation". 13

As regards climate litigation before the European Court of Human Rights (ECtHR), following the general approach in environmental cases, applicants have invoked respondent states' obligations deriving from Article 2 (the right to life) and Article 8 (the right to respect for private and family life). ${ }^{14}$ An indicative example can be found in the pending case Duarte Agostinho and Others v. Portugal and 32 Other States. ${ }^{15}$

\footnotetext{
${ }^{7}$ Case T-330/18 ArmandoCarvahlo et al. v. European Parliament and Council of the European Union, ECLI:EU:T:2019:324 and on appeal Case C-565/19 P ArmandoCarvahlo et al. against the order of the General Court, ECLI:EU:C:2021:252.

${ }^{8}$ Case T-141/19 Peter Sabo et al.v. European Parliament and Council of the European Union, ECLI:EU:T:2020:179 and on appeal Case C-297/20 P Peter Sabo et al.v. European Parliament and Council of the European Union, ECLI:EU:C:2021:24.

${ }^{9}$ In a nutshell, in the first case, the plaintiffs -all working in the agricultural or tourism sectors- brought suit against the EU legislature arguing that the measures taken by the EU to mitigate GHG emissions are insufficient to meet the overall emission reduction target of $40 \%$ compared with 1990 levels, whereas in the second case, the plaintiffs challenged a piece of EU legislation that allows the burning of "forest biomass" claiming that this leads to increased release of carbon into the atmosphere despite its conception as a carbon neutral energy source. See, Savaresi and Auz [21], p. 256-258.

${ }^{10}$ According to Article 263(4) TFEU, "Any natural or legal person may [... ] institute proceedings against an act addressed to that person or which is of direct and individual concern to them, and against a regulatory act which is of direct concern to them and does not entail implementing measures."

${ }^{11}$ Case C-25/62 Plaumann v Commission of the EEC, ECLI:EU:C:1963:17. See, Pagano [18], p. 311; Krämer [12], p. 32.

${ }^{12}$ Hartmann and Willers QC [7].

${ }^{13}$ Krämer [12], p. 33.

${ }^{14}$ Kobylarz [10].

${ }^{15}$ Youth4ClimateJustice, 'An emergency like no other', Global Leal Action Network (2021). https:// youth4climatejustice.org/.
} 
In brief, in September 2020, six Portuguese children and young adults, aged 8 to 21, made an application to the European Court of Human Rights against 33 Council of Europe Member States (the 27 Member States plus the UK, Switzerland, Norway, Russia, Turkey and Ukraine) for failing to reduce sufficiently emissions from their territories and for contributing to overseas emissions, thus affecting the plaintiffs in the present and in the future: these emissions worsened climate change effects, which violated the complainants' rights to life and private and family life, according to Articles 2 and 8 of the Convention. ${ }^{16}$ In Union of Swiss Senior Women for Climate Protection v. Swiss Federal Council, another group that was particularly vulnerable to the effects of climate change brought a case before the Court of Human Rights in the wake of an unsuccessful outcome to litigation at domestic level. Namely, a group of Swiss senior citizens argued that by failing to take steps to reduce global temperature increases, the Swiss government had violated their right to life. This case is still pending.

Based on these introductory thoughts, the second section of the paper delves into the key features of climate-related cases with emphasis on the different categories of climate litigation and the different grounds of review. The analysis will focus on unpacking recent judgments emanating from different Member States such as the Netherlands, France, Ireland, Belgium, Spain, Germany, and Italy. In the third section, two legally complex issues will be addressed: as will the role of science in climate litigation and the increasing judicialisation of the climate crisis. Finally, some concluding remarks about the challenges and the opportunities of climate change litigation in the European Union will be made.

\section{Climate change litigation: a diverse toolbox}

Climate litigation has by now evolved from being a legal experiment promoted by climate activists and monitored by legal scholars into a mainstream global phenomenon with repercussions for governments, the business sector and society. The main driving force behind this "climate litigation boom" lies in the well-known failure on the part of national governments to live up to the obligations enshrined in the Paris Agreement and the constantly increasing pressure created by the climate crisis. The lack of ambition and commitment which has been shown as well as the inherent weaknesses of the Paris Agreement ${ }^{17}$ show that we are not on the right track to achieving climate change objectives. Hence, climate litigation has emerged as a new pathway to spur global action to address the climate crisis and limit its harmful effects.

\subsection{Different types of climate litigation}

As mentioned above, climate litigation consists of a broad range of legal proceedings and categories of proceeding that relate in some way to climate change and its effects.

\footnotetext{
${ }^{16}$ Clark, Liston and Kalpouzos [5].

${ }^{17}$ Tellingly, there is no mechanism to review the adequacy of the nationally determined contributions (NDCs) and no obligation of result attached to the content of the nationally determined contributions. See, Voigt [30], pp. 166-168.
} 
Globally, the cumulative number of climate change-related cases has more than doubled since 2015. More specifically, while just over 800 cases were filed between 1986 and 2014 , over 1000 cases have been brought in the last six years. ${ }^{18}$ The explosion of climate cases coupled with their complexity and the different grounds of review makes their categorisation a challenging exercise. In this context, for the purpose of this paper, three main types of climate cases have been identified: i. actions against governments (strategic litigation), ii. actions against decision-makers and iii. actions within the private sector.

\subsubsection{Actions against governments}

Strategic litigation is an emerging trend globally. The concept of strategic litigation refers to actions that aim at bringing about some broader societal shift and that are usually linked to emission reduction targets and to the Paris Agreement. They are called "strategic" because they seek to lead to wider changes in the public climate policy, to create public awareness or to change the behaviour of governments or industry actors. ${ }^{19}$ These actions are typically brought by non-governmental organisations and pressure groups and focus on holding governments to account for perceived failures in relation to the enforcement of climate commitments. Emphasis is placed on governments' actions or omissions that have allegedly led to an increase in greenhouse gas emissions or an insufficient decrease in emissions, or a failure to adapt to climate change. Recently, there have been many successful climate cases within this category across Europe.

At European level, the case of Urgenda Foundation v. State of the Netherlands was the first piece of litigation "in which citizens established that their government has a legal duty to prevent dangerous climate change". ${ }^{20}$ In a nutshell, the Urgenda Foundation initiated legal proceedings against the Netherlands in November $2013^{21}$ claiming that that State was negatively contributing to the dangerous effects of climate change and that Dutch emissions were unlawful because they violated the State's duty of care, according to Dutch Civil Law and Articles 2 and 8 of the European Convention of Human Rights. On 24 June 2015, the District Court concluded that the State must limit the combined volume of Dutch annual greenhouse gas emissions or cause them to be limited, so that they will have been reduced by at least $25 \%$ at the end of 2020 compared to the level at which they stood in $1990 .^{22}$ In April 2016, the Dutch State submitted grounds for an appeal, and, in October 2018, the Court of Appeal decided to uphold the 2015 Court decision. On 8 January 2019, the State further ap-

\footnotetext{
${ }^{18}$ Setzer and Higham [23], p. 10.

${ }^{19}$ Setzer and Byrnes [22].

${ }^{20}$ Van Berkel, [3].

21 Ibid.

${ }^{22}$ Supreme Court of the Netherlands, ECLI:NL:HR:2019:2007 paragraph 2.2.1, 2.2.2, 2.3.1 (2020). https://www.urgenda.nl/wp-content/uploads/ENG-Dutch-Supreme-Court-Urgenda-v-Netherlands-20-122019.pdf.
} 
pealed to the Netherlands Supreme Court, ${ }^{23}$ which, on 20 December 2019, rejected this appeal. ${ }^{24}$

A similar case-inspired by the Urgenda judgment-is VZW Klimaatzaak v. Kingdom of Belgium. ${ }^{25}$ In this case, the plaintiffs alleged that Belgian law required the government to adopt more ambitious climate mitigation goals than it had previously done based on the Article 1382 of the Belgian Civil Code. In this context, they ask the court an injunction against the government to reduce emissions from $42 \%$ to $48 \%$ by 2025 and to, at least, from $55 \%$ to $65 \%$ by 2030 . The case is still ongoing, and the final decision is expected before next summer.

Friends of the Irish Environment v. Government of Ireland is another recent climate change case, this time from Ireland. Briefly, on 19 July 2017, the Government of Ireland approved the National Mitigation Plan. The advocacy group Friends of the Irish Environment filed a suit in the High Court against the State, claiming that the National Mitigation Plan failed to specify the manner in which it is supposed to achieve the "national transition objective" of a 25\% to $40 \%$ reduction from 1990 levels of GHG emissions by 2020 as required by the Climate Action and Low Carbon Development Act 2015. ${ }^{26}$ The claimant also argued that the National Mitigation Plan contravened the right to life, the right to bodily integrity and the right to an environment according to the Constitution of Ireland and violated the right to life and the right to private and family life under the European Convention of Human Rights. ${ }^{27}$ The High Court rejected FIE's claims, arguing that a wide measure of discretion ought to be afforded to the Executive ${ }^{28}$ and that the 2015 Act did not prescribe any statutory obligation to achieve intermediate targets. ${ }^{29}$ Moreover, the National Mitigation Plan was to be considered a step towards a national policy on climate change, and so was not regarded as violating any human right. ${ }^{30}$ On 15 November 2019, Friends of the Irish Environment appealed to the Supreme Court, which, on 31 July 2020, concluded that the Plan did not specify how Ireland would achieve its 2050 goals so as to comply with the provisions of the 2015 Act. The Government must now create a new, more ambitious National Mitigation Plan that complies with Ireland's national and international climate obligations.

Recent developments in France also reflect the willingness of the courts in some jurisdictions to hold governments accountable in terms of their climate change obligations. Namely, in Commune de Grande-Synthe v. France, the Council of State (France's highest administrative court) ruled that the French government had failed

\footnotetext{
${ }^{23}$ Van Berkel, [3].

${ }^{24}$ Supreme Court of the Netherlands, ECLI:NL:HR:2019:2007 para. 9, Available at: https://www.urgenda. nl/wp-content/uploads/ENG-Dutch-Supreme-Court-Urgenda-v-Netherlands-20-12-2019.pdf.

${ }^{25}$ https://www.asil.org/insights/volume/25/issue/21.

${ }^{26}$ High Court of Ireland, Friends of the Irish Environment v. Ireland, para. 64, available at: http:// climatecasechart.com/climate-change-litigation/wp-content/uploads/sites/16/non-us-case-documents/ 2019/20190919_2017-No.-793-JR_judgment-2.pdf.

${ }^{27}$ Ibid., para. 71.

${ }^{28}$ Ibid., para. 94.

${ }^{29}$ Ibid., para. 117.

${ }^{30}$ Ibid., para. 133.
} 
to take sufficient action to mitigate climate change and ordered it to take additional measures to address that failure. In a nutshell, on 23 January 2019, the municipality of Grande-Synthe, which is located below sea level and is exposed to increased natural risks induced by climate change such as flooding and the complicated management of water systems, sued the French State asking the Court to order the government to take legislative and regulatory measures to make prioritising the climate mandatory and to prohibit any measure likely to increase greenhouse gas emissions. ${ }^{31}$ On 19 November 2020, the Council of State decided that the case was admissible and instructed the government to establish its ability to comply with the commitment to a $40 \%$ reduction in greenhouse gas emissions by 2030 , without stricter measures. ${ }^{32}$ Finally, on 1 July 2021, the Council condemned the failure of the French government to comply with its own targets, which were a $40 \%$ emissions reduction by 2030 and carbon neutrality by $2050 . .^{33}$

Additionally, in Oxfam France, Notre Affaire à Tous and Others v. France, the Administrative Court of Paris in a judgment of 14 October 2021 ruled that France failed to take immediate and concrete actions in order to comply with its commitments to cut carbon emissions, violating a statutory duty to act under domestic and international law. In short, in December 2018, Oxfam France, Notre Affaire à Tous, the Nicolas Hulot Foundation, and Greenpeace France lodged an administrative appeal against the French State for failing to reduce the country's emissions fast enough to meet its commitments. ${ }^{34}$ On 15 February 2019, the French government rejected the plaintiffs' request. On 14 March 2019, the NGOs therefore initiated a lawsuit, filing a summary request before the Administrative Court of Paris to order France to take proper measures to: (i) achieve France's goals for reducing emissions; (ii) develop renewable energies, and increase energy efficiency; (iii) adapt the national territory to the effects of climate change; and (iv) protect citizens' lives and health. They argued that citizens have the right to life and the right to respect for private and family life, according to Articles 2 and 8 of the European Convention on Human Rights. ${ }^{35}$ On 3 February 2021, the Administrative Court of Paris issued a decision recognising that France's inaction against climate change had caused ecological damage. Moreover, it ordered the State to pay the symbolic sum of one euro in compensation for the moral damage suffered and the same symbolic sum for ecological damage, while ordering that the Prime Minister and the competent ministers should put an end to all the failures to take enough action to tackle climate change or remedy its effects.

Moving to Germany, a ruling was recently handed down by the Bundesverfassungsgericht (Constitutional Court) in Neubauer et al. v. Germany, in which German young people together with non-governmental organisations challenged the constitutionality of the Federal Climate Protection Law (Klimaschutzgesetz) of 2013 (as

\footnotetext{
${ }^{31}$ Commune de Grande-Synthe v. France, Climate Case Chart 2021: http://climatecasechart.com/ climate-change-litigation/wp-content/uploads/sites/16/non-us-case-documents/2019/20190123_Not-YetAvailable_press-release-1.pdf.

32 Ibid.

${ }^{33}$ Lavrysen [13].

${ }^{34}$ Tenwick, [26].

${ }^{35}$ Notre Affaire à Tous and Others v. France, Climate Case Chart 2021: http://climatecasechart.com/ climate-change-litigation/non-us-case/notre-affaire-a-tous-and-others-v-france/.
} 
subsequently amended in 2019), on constitutional and human rights grounds. The main argument focused on the fact that the State had not adopted and implemented sufficient regulations for the immediate reduction of greenhouse gases, especially $\mathrm{CO}_{2}$, this being necessary to prevent the temperature increasing by 1.5 degrees. The court upheld the claim by the plaintiff youths and asked the Government to revise the Law without, however, referring to the introduction of specific provisions or targets within a specific time frame. Some weeks after the judgment, the German Cabinet approved proposals to raise their climate mitigation target to net-zero greenhouse gas emissions by 2045 , also setting a target to reduce emissions by $65 \%$ by $2030 .^{36}$

Finally, in Greenpeace Netherlands v. State of the Netherlands, ${ }^{37}$ Greenpeace challenged the Dutch Government's provision of a Coronavirus bailout package to the airline KLM on the basis that the Government had violated its duty of care to prevent dangerous climate change by failing to attach stringent conditions. More specifically, in July 2020, the Dutch government granted State aid to KLM due to the impact of the Coronavirus pandemic. The financial support consisted of a loan of EUR 3.4 billion. The Dutch government imposed some conditions relating to sustainability, which included a reduction of the company's $\mathrm{CO}_{2}$ emissions. ${ }^{38}$ On 7 October 2020 , Greenpeace Netherlands initiated legal proceedings against the Dutch State to force the government to impose stricter conditions on KLM to mitigate the effects of climate change, arguing that the State has a positive duty of care to protect citizens. ${ }^{39}$ Given that the executive has a wide margin of discretion, the judge in such a case is limited to intervene only when a positive legal right has been violated. Therefore, on 9 December 2020, the District Court of The Hague rejected the claim on the grounds that the State was not required to attach climate conditions to the aid package. According to the court, the United Nations Framework Convention on Climate Change and the Paris Agreement do not require the reduction of $\mathrm{CO}_{2}$ emissions in international aviation, so that the Dutch State can only be held responsible for emissions within the country. Moreover, the emission cap claimed by Greenpeace went beyond the climate goals for the aviation section which had been agreed internationally. ${ }^{40}$

\subsubsection{Actions against decision-makers}

The second category of climate cases concerns actions against decision-makers challenging decisions to grant licences, permits and planning permission. This concerns the authorisation of third-party activities which contribute to the increase of greenhouse gases emissions, such as projects in the energy sector. These cases typically include challenges to the approval processes for new fossil-fuel-intensive projects such as coal mines (e.g., Sharma v. Minister for the Environment) or airport expansions (e.g., Plan B v. Secretary of State for Transport - the 'Heathrow case'). ${ }^{41}$ All

\footnotetext{
${ }^{36}$ Setzer and Higham [23], p. 19.

${ }^{37}$ Greenpeace Netherlands v. State of the Netherlands - Climate Change Litigation (climatecasechart.com).

${ }^{38}$ Luycks and Hendrikx, [14].

${ }^{39}$ Meijer [16].

${ }^{40}$ Luycks and Hendrikx, [14].

${ }^{41}$ United Nations Environmental Programme [28], p. 20.
} 
these cases cite both the long-term, global effect of investing in projects that will produce consumable fossil fuels and the local impacts on water, land use and air quality associated with mining and drilling activities.

Indicatively, in Greecepeace Nordic Association v. Norway Ministry of Petroleum and Energy, ${ }^{42}$ environmental non-governmental organisations argued that Norway's Ministry of Petroleum and Energy violated the Norwegian constitution by issuing a block of oil and gas licences for deep-sea extraction from sites in the Barents Sea. The plaintiffs challenged the State's decision to grant these offshore oil and gas development licences given the project's climate change implications.

\subsubsection{Actions within the private sector}

Actions within the private sector involve cases that are brought directly against a private sector company or a financial institution which undertakes activities that negatively contribute to the climate crisis. This type of climate change litigation has been dominated by claims against fossil fuel companies (i.e., companies involved in the extraction, refining and sale of fossil fuels) and tends to be based on arguments that the activities of these companies are directly related to emissions associated with climate change. ${ }^{43}$ This type of climate litigation is closely related to the environmental, social and governance (ESG) criteria used by investors to evaluate companies and determine their future financial performance. Insofar as concerns the environmental aspect, which is the most relevant for climate litigation, factors such as climate change, natural resources, pollution as well as environmental prospects are taken into account in order to assess the environmental risks that a company might face. The integration of environmental, social and governance considerations into companies' long-term strategies as a crucial factor in investment analyses and decision-making processes is reflected in the Principles for Responsible Investment developed by a United Nations-supported international network of investors. ${ }^{44}$

Falling within this category of cases is the historic ruling issued by the District Court of the Hague in Milieudefensie et al. v. Royal Dutch Shell plc.. The associations Milieudefensie, Greenpeace Nederland, Fossielvrij NL, Waddenvereniging, Both Ends, Jongeren Milieu Actief and ActionAid filed a suit against Royal Dutch Shell (RDS). Extending the argument developed in the Urgenda case to private companies, the plaintiffs claimed that Royal Dutch Shell had the obligation to reduce its emissions volume of $\mathrm{CO}_{2}$, since its climate policy was not in accordance with Article 2, paragraph 1, of the Paris Agreement and, thus, was in violation of the human right to life enshrined in Article 6:162 of the Dutch Civil Code and Articles 2 and 8 of the European Convention on Human Rights. ${ }^{45}$ Taking into account Shell's long knowledge of climate change, misleading statements on climate change and inadequate action to reduce climate change serves to support the aforementioned argument. Hence, the District Court of the Hague concluded that RDS was obliged to reduce the $\mathrm{CO}_{2}$

\footnotetext{
${ }^{42}$ Voigt [29].

${ }^{43}$ Setzer and Higham [23], p. 25-26.

${ }^{44}$ OECD [17].

${ }^{45}$ Macchi and van Zeben, [15], p. 4-5.
} 
emissions of the Shell group's activities by net $45 \%$ by the end of 2030 , compared to 2019 levels. ${ }^{46}$ Moreover, the Court made its decision provisionally enforceable, meaning Shell would be required to meet its reduction obligation even if the case was appealed.

In Notre Affaire à Tous v. Total, the claimants relied on France's corporate due diligence legislation which requires corporate actors to adopt measures to protect human rights and the environment. Based on that they asked the court to order oil gas company Total to recognise the risks generated by its business activities and align its conduct with the goal of limiting global warming to $1.5^{\circ} \mathrm{C}$. This was the first French climate lawsuit against a fossil fuel company. More specifically, on 28 January 2020, several French Associations including Notre Affaire à Tous, Sherpa, ZEA, les Eco Maires, and others initiated legal proceedings against the multinational petrol company Total. Every year, the Total Group is responsible for $1 \%$ of the total greenhouse gas emissions worldwide and in 2017 it was considered one of the 20 companies that contribute to the climate change in the world. The non-governmental organisations argued that the company did not have a proper plan to reduce its greenhouse gas emissions ("plan de vigilance"), despite its legal obligations. In this context, they asked the Nanterre High Court to order Total to recognise the risks generated by its activities and to align with a trajectory compatible with limiting global warming to $1.5^{\circ} \mathrm{C}$. The court has not yet arrived at a decision in this case. ${ }^{47}$

\subsection{Different grounds of review}

Building on the above classification of climate cases, emphasis will be now placed on the different claims brought by the plaintiffs in each category. In most of the climate cases, more than one type of legal claims is invoked. Climate litigation at the European landscape typically falls into one of the following clusters of legal claims: ${ }^{48}$

\section{- Breach of International Law Obligations}

It refers to claims focusing on the cases where governments have a legally binding obligation under international law and do not comply with it, either through their actions or through omissions. Since the adoption of the Paris Agreement, the arguments relating to the lack of compliance with climate commitments enshrined in international law have multiplied. Many of the most significant recent cases seek to hold governments to account for a failure to act in a manner that is consistent with their share of the global responsibility to mitigate and/or adapt to climate change. ${ }^{49}$

\footnotetext{
${ }^{46}$ The court ordered Royal Dutch Shell, both directly and via the companies and legal entities it commonly included in its consolidated annual accounts and with which it jointly formed the Shell group, to limit or cause to be limited the aggregate annual volume of all $\mathrm{CO}_{2}$ emissions into the atmosphere (Scope 1,2 and 3 ) due to the business operations and sold energy-carrying products of the Shell group to such an extent that this volume would have reduced by at least net $45 \%$ by the end of 2030 , relative to 2019 levels. The Hague District Court, Case Number C/09/571932/HA ZA 19-379' (2021). https://uitspraken.rechtspraak. nl/inziendocument?id=ECLI:NL:RBDHA:2021:5339.

${ }^{47}$ Action en justice contre Total, Notre Affaire à Tous 2020, available at: https://notreaffaireatous. org/actions/les-territoires-qui-se-defendent-et-si-nous-mettions-enfin-les-entreprises-face-a-leursresponsabilites/.

${ }^{48}$ Sindico, Mbengue and McKenzie [24], pp. 9-17.

${ }^{49}$ Setzer and Higham [23], p. 23.
} 
This approach has been adopted in the landmark cases of Urgenda, the Friends of the Irish Environment and Grande-Synthe v. France.

\section{- Constitutional and Human Rights}

Climate change is now widely recognised as the "greatest human rights issue of our time," 50 since the insufficient action to mitigate climate change violates the plaintiffs' international and constitutional rights to life, health, family life, water and food. Taking the human rights grounds pathway has progressively become an increasingly common practice in climate action both globally and across Europe. ${ }^{51}$ Indicatively, in Neubauer et al. v. Germany, the court found that the proposed Federal Climate Protection Law was incompatible with fundamental constitutional rights as it failed to make sufficient provision for cuts in greenhouse gas emissions beyond 2030 and, by extension, prejudiced future generations. By failing to take precautionary steps, the Law "irreversibly offloaded major emission reduction burdens onto periods after 2030." 52

Furthermore, in Urgenda, the Supreme Court of the Netherlands ruled that Articles 2 and 8 of the European Convention of Human Rights (ECHR), as integrated into domestic Dutch law, impose enforceable obligations on the state to protect both the right to life and the right to respect for private and family life. The court concluded that those obligations require the government to take steps to reduce carbon emissions consistent with limiting global warming increase to an average of $1.5^{\circ} \mathrm{C} .{ }^{53}$ Along similar lines, VZW Klimaatzaak claimed the State had failed in its obligation to act diligently and reasonably as a "bonus pater familias" towards its citizens, so as to avoid the risks linked to climate change, which may occur as damage to health, to property, but also as damage to the general well-being resulting, for example, from the propagation of tropical diseases, or the intensification of heat waves. However, in Union of Swiss Senior Women for Climate Protection v. Swiss Federal Council and Others (currently pending before the European Court of Human Rights) the national court rejected the claims that the Swiss authorities had failed to fulfil their duty to protect them as required by the Swiss Constitution and by the European Convention of Human Rights, focusing on the fact that the petitioners were not the only demographic affected by climate change. Hence, neither the injury nor remedy was particular to the petitioners. ${ }^{54}$

\section{- Tort Law}

A further ground to consider is tort law (and especially the tort of negligence) and the breach of the standard of due care. In this framework, a court will be asked to judge whether a State has met its duty of care towards its citizens when it comes to its actions to mitigate climate change. This legal avenue has been used in the Urgenda and Notre Affaire à Tous and others v. France cases. Both actions were based on

\footnotetext{
${ }^{50}$ Setzer and Higham [23], p. 2017.

${ }^{51}$ Peel and Osofsky [20], p. 40.

${ }^{52}$ Neubauer, et al. v. Germany - Climate Change Litigation (climatecasechart.com).

${ }^{53}$ Backes and van der Veen [2], p. 312-313.

${ }^{54}$ United Nations Environmental Programme [28], p. 16.
} 
the relevant articles of the Civil Code (Art. 162 of the Dutch Civil Code and Art. 1249 of the French Civil Code, respectively) and challenged the sufficiency of the defendants' actions in the battle against climate change by testing whether the States had fulfilled their duty of care towards their citizens. Actions in tort could also be brought against private actors for their actions leading to a rise in greenhouse gas emissions, provided that the individual was able to show a relationship between the damage suffered and the actions undertaken by a private actor. ${ }^{55}$ However, it should be noted that the number of cases within this category is limited - in part, due to the numerous hurdles faced by the claimants seeking to rely on the torts of negligence and nuisance in the climate context, particularly in common law jurisdictions. ${ }^{56}$

Within the context of tort law on climate action being deployed against the private sector, a new trend has emerged from existing cases regarding the recognition of corporate human rights responsibilities. Namely, Milieudefensie et al. v. Royal Dutch Shell plc. relied on human rights law to define the scope of the corporate duty of care and due diligence obligations under national tort law. As 'forward looking' cases focused on major emitters' activities and investment decisions from the present day and into the coming decades, cases like this seek a declaration from courts that fossil fuel companies' climate change targets should be aligned with those of the Paris Agreement. ${ }^{57}$ In France, non-governmental organisation Notre Affaire à Tous and citizens relied on France's corporate due diligence legislation that requires corporate actors to adopt measures to protect human rights and the environment.

\section{- Administrative Law}

This ground is mainly linked to cases coming under the second category of climate actions analysed in the previous section (i.e., actions against decision-makers). What is involved here are challenges to the merits of administrative decision-making within existing on-the-books laws, such as in e.g., the granting of permissions for highemissions projects. Judicial review is mainly used against decisions by governments or public authorities to authorise socio-economic activities that could lead to a rise in greenhouse gas emissions, hence contributing to climate change. ${ }^{58}$ An example of this is the ruling that was issued in ClientEarth v. PolskaGrupaEnergetyczna case, determining that Europe's largest power plant, Belchatow, will have to reduce its greenhouse gas emissions. ${ }^{59}$

\section{Challenges in climate change litigation in Europe}

In general, the perception of climate change (like many other environmental problems) is enormously difficult, as it is impossible for (human) beings to see or experience "global warming" as such. ${ }^{60}$ Although, increasingly frequently over the years,

\footnotetext{
${ }^{55}$ Sindico, Mbengue and McKenzie [24], p. 12.

${ }^{56}$ Setzer and Higham [23], p. 25.

${ }^{57}$ Setzer and Higham [23], p. 29-30.

${ }^{58}$ Sindico, Mbengue and McKenzie [24], p. 13-14.

${ }^{59}$ Setzer and Higham [23], p. 30.

${ }^{60}$ Trexler [27], p. 205.
} 
humans across the globe have had to grapple with (more or less) extreme weather events as a result of the climate crisis, they still treat these events as isolated incidents without being in a position to grasp and see the bigger picture. The "tricky" and "enormously difficult task" of imagining global warming not only challenges "our" cultural imagination and philosophical discourses. It also pushes "our" political thinking and legal imagination to their limits. ${ }^{61}$

Since the adoption of the Paris Agreement, a series of drivers has emerged, foreshadowing the climate litigation boom across Europe and globally. Firstly, there is the proliferation of national and international agreements and commitments on climate change. Within the EU, the objective is to reduce greenhouse gas emissions by $40 \%$ by 2030 , compared to 1990 , while by 2050 , EU-wide greenhouse gas emissions are supposed to be reduced by $80-90 \%$ compared to 1990 . In addition, climate neutrality has been placed at the epicentre of the EU Green Deal incorporating climate objectives into all EU policies. In this context, the enforcement of these laws and regulations has led to regulatory investigations, sanctions, and litigation. ${ }^{62}$ Another such driving force consists of developments in climate science, given that the detection and causal attribution of a defendant's emissions to climate change overall ("source attribution") and the linking of climate change to specific climate change impacts ("impact attribution") involves applying a combination of statistical analyses and physical knowledge about the climate system's complexities. ${ }^{63}$ Last but not least, increased societal awareness and activist movements, in particular from the younger generations, such as the "Fridays for Future" movement ${ }^{64}$ have pushed the climate crisis to the forefront of public discourse and policy making.

Climate litigation in Europe has emerged as a tool to leverage some more ambitious climate policies and actions, whereby both governments and corporates are being targeted with the aspiration of either enforcing effectively or tightening domestic climate governance regimes. However, the road to the genesis and evolution of climate litigation in Europe is not strewn with thornless flowers. As briefly analysed in the introduction, the contribution of the courts to climate protection at regional level has been of limited substantive significance so far. As regards domestic jurisdictions, certain challenges exist which are similar to those in environmental law cases in general-such as obstacles to access to justice, lack of judicial capacity or of the legal culture to deal with these questions and the absence of climate awareness. In addition to this, two issues have been particularly taxing in the context of climate-related cases: the role of science and the role of judges.

\subsection{The role of attribution science in climate cases}

According to the Assessment Report from 2013 by the Intergovernmental Panel on Climate Change (IPCC), the concentration of $\mathrm{CO}_{2}$ and other greenhouse gases additionally present in the atmosphere deriving from anthropocentric sources (i.e., the

\footnotetext{
${ }^{61}$ Kloepfer and Neugärtner [11], p. 23.

${ }^{62}$ The Geneva Association [6], p. 25.

${ }^{63}$ Weller, Nasse, Nasse [31], p. 385.

${ }^{64} \mathrm{www}$.fridaysforfuture.org.
} 
intensive use of fossil fuels) is very likely the reason for the climate change that has already been observed. ${ }^{65}$ However, how can we link locally-emitted greenhouse gases spread evenly through the entire atmosphere with damage to an individual or to a (single) new project in the energy sector affecting the climate? Attribution science is a field of research that applies counterfactuals to identify the extent to which human influence is associated with specific weather- or climate-related events becoming more likely or more severe. ${ }^{66}$ Ongoing advancements in attribution science have been important for the development of climate litigation involving the world's largest greenhouse gas-emitting companies.

In this context, cases seeking to assign climate-mitigation obligations to governments or corporations under rights-based theories, and cases seeking to impose liability on private actors for their contribution to climate change may begin to enter more formal evidentiary stages of litigation in the coming years. ${ }^{67}$ In climate-related lawsuits, in order to establish a causal link between a factor influencing the climate system's energy balance (such as an increased $\mathrm{CO}_{2}$ concentration), and an observable parameter like the global mean surface temperature, it is first necessary to detect a statistically significant change in this parameter, above and beyond its natural variability, and then to prove the factor in question had a causal influence on the parameter. ${ }^{68}$ Given that scientific findings cannot always be translated and applied to concrete cases, the exercise of aligning scientific research methods with evidentiary requirements in legal settings remains a challenge both for scientists and lawyers.

\subsection{The role of courts in climate protection}

This climate litigation boom at European landscape has opened a debate on the role of the courts in climate protection raising questions on the separation of powers in constitutional democracies especially in cases where the court is asked to issue an order that would invade the authority granted to another branch of government. The main criticism lies on the question of legitimacy of courts in tackling climate change policies and, more particular, the balance between the national legislative power and the judicial system's role in climate-related cases. To what extent is a court permitted to legitimately exercise power over a state's designated climate policy? And when is its involvement in advancing far-reaching climate protection objectives to be deemed to overstep the boundaries of the law, and to enter the realm of politics ${ }^{69}$ ?

This issue of separation or balance of powers is comprehensively reflected in Friends of the Irish Environment v. Government of Ireland. Here, the Irish Government argued that the Plan relied upon constituted a policy document and is not justiciable. Hence, its judicial review would amount to an impermissible venture by the courts into areas of policy. The lower court shared this scepticism, asserting that "there may be circumstances in which a court may make a mandatory order against an

\footnotetext{
${ }^{65}$ Weller, Nasse, Nasse [31], p. 384.

${ }^{66}$ The Geneva Association [6], p. 27-28.

${ }^{67}$ United Nations Environmental Programme [28], p. 31.

${ }^{68}$ Weller, Nasse, Nasse [31], p. 385.

${ }^{69}$ Payandeh [19], p. 76.
} 
organ of State, but only when there is a ... conscious and deliberate decision by the organ of the State to act in breach of its constitutional obligations to other parties". ${ }^{70}$ A similar criticism was expressed by Royal Dutch Shell in the Milieudefensie case, stressing that complex societal challenges should not be addressed by the courts.

It is therefore apparent that the global climate ligation trend imposes the question of how the judiciary should respond to claims without violating their democraticallydetermined role according to the separation of powers. ${ }^{71}$ In other words, in this new type of litigation, is the judge asked to play a lead role not only as the controller of the effective application of the existing climate laws but also as a potential accelerator of a more ambitious climate policy in line with international commitments, and, if so, on what grounds? These questions are much more relevant in cases where the court has deduced mitigation targets or adaptation consequences from general legal principles and rules. ${ }^{72}$ Although striking the balance between climate-activist judicial lawmaking and respect for the institutional boundaries of democratic legitimisation is a new and challenging exercise in progress, according to a more optimistic approach, "every time a climate lawsuit is launched, the following legal position is reinforced: the climate has moved on from the stage of political debate, as environmental protection is a constitutional - a legal - matter". ${ }^{73}$

Another significant criticism concerns the general position that courts are not the appropriate forum to address climate change. ${ }^{74}$ This critical reflection on the role of courts is based on the peculiarities of climate change as a "super wicked problem", encompassing the relationship between cause and effect, the interplay between anthropogenic measures and natural circumstances, the scientific uncertainties surrounding climate change, the relevance of different actors and finally the interplay between environmental concerns and other economic interests. ${ }^{75}$ Hence, in some countries the judiciary might not feel very "comfortable" in exercising scrutiny vis$\grave{a}$-vis the executive branch of the government in climate-related measures based on complex technical, scientific and political assessments, as they might not have the general expertise and the technical knowledge to deal with such cases by interpreting scientific reports into legal answers. Indicatively, this approach is reflected in the decision of the Oslo District Court not to consider a claim brought by the youth organisation Natur og Ungdom against the Norwegian State for the authorisation of oil extraction projects. ${ }^{76}$

\section{Conclusions}

In sum, although climate litigation is still in its infancy on the European legal landscape (i.e., in comparison with the USA or Australia), it has become clear that it

\footnotetext{
7020190919_2017-No.-793-JR_judgment-2.pdf (climatecasechart.com), para. 92.

${ }^{71}$ Burgers [4], p. 59.

${ }^{72}$ Payandeh [19], p. 78.

${ }^{73}$ Burgers [4], p. 72.

${ }^{74}$ Payandeh [19], p. 78.

${ }^{75}$ Ibid.

${ }^{76}$ Greenpeace Norway v. Norwegian State, Oslo District Court, 4 January 2018, Case No. 16-166674TVIOTIR/06, para. 5.2.7.
} 
constitutes the "vehicle" to address the lack of effort and regulation by the governments. The absence of legally binding obligations or strong enforcement mechanisms in the Paris Agreement has not acted as a drag on the constantly-increasing number of climate cases, with many of them relying directly or indirectly on it. As highlighted by The Hague district court in Milieudefensie v. Shell, the $1.5^{\circ} \mathrm{C}$ temperature limit should be used to inform a legal standard of conduct, even in the absence of explicit legislation, recognising that the "non-binding" goals of the Paris Agreement represent a universally endorsed and accepted standard that protects the common interest of preventing dangerous climate change. ${ }^{77}$

Bringing the climate crisis into the courtroom has been demonstrated to be an effective way to advance climate action. Apart from the successful climate-related legal actions, it has been noted that there are positive spill-over effects even to unsuccessful cases which should not be ignored. More specifically, at regional level, while attempts to challenge climate legislation adopted at EU level [mu Dym adopted at EU level?] have been rejected on admissibility grounds, the reform of EU law announced in 2020 shows that many plaintiffs' requests [mu Dym arguments?] have been taken into account in shaping the new policies despite the outcome in the courtroom. ${ }^{78}$

In the same vein, as regards corporate activities and business decisions, a case may have effects beyond the courtroom (even if it is unsuccessful) such as changing corporate behaviour when there is an increasing risk of litigation. As commentators have observed, this is clearly reflected in the Shell case where the court relied on the "unwritten duty of care" under Dutch tort law and the use of non-binding instruments such as the UN Guiding Principles on Business and Human Rights, and the OECD's Guidelines for Multinational Enterprises. ${ }^{79}$ These international standards and the factual background of the Shell case arguably make it replicable, increasing the risk of litigation against companies that set net-zero targets without taking credible shortterm action in pursuit of this, with knock-on effects expected for the cost of capital for oil and gas projects. ${ }^{80}$

All in all, in the aftermath of these landmark cases, the relationship between climate litigation and climate-oriented policies and legislations remains to be seen. Certainly, climate litigation has been the best context in which to test strategies and trends in different jurisdictions, to improve the dialogue between legal scholars and scientists as well as to force society-wide deliberations on how climate crisis can be tackled. However, what still remains to be examined is the impact of the increasing number of climate cases on the evolution of legal culture and citizens' awareness in countries where there are not any climate actions yet. In Europe, Italy is the most recent addition to the group of countries with climate cases. ${ }^{81}$ In parallel, new emerging types of climate cases have been identified focusing on consumer and investor fraud

${ }^{77}$ Setzer and Higham [23], p. 35.

${ }^{78}$ Hartmann and Willers QC [7], p. 19.

79 van Asselt, Kulovesi, Rajavuori, and Savaresi, [1].

${ }^{80}$ Khan [9]; Macchi and van Zeben, [15], p. 2.

${ }^{81}$ A Sud et al. v. Italy case. See, A Sud et al. v. Italy - Climate Change Litigation (climatecasechart.com). 
claims. Pre- and post-disaster cases have become more common, and the use of international adjudicatory bodies has increased. ${ }^{82}$

It is undeniable that climate litigation has increased in volume, expanded in scope and geographical coverage and has evolved, opening up a new approach to fighting the climate crisis. However, many unanswered questions lie before us and it should always be noted that "judicial decision making is a responsive mechanism and is therefore always the second-best option for solving pressing societal problems compared with legislation enacted through democratic channels". ${ }^{83}$ According to Tessa Kahn, an environmental lawyer on the Urgenda case, "lawsuits are not a panacea. It takes significant public vigilance and pressure to ensure that judgments translate into real change. But litigation is one of the most powerful tools we have for claiming our rights and making clear what's at stake - and the stakes have never been higher". Hence, as regards judicial engagement with climate change, we are still a long way from a comprehensive assessment of its overall impact on the climate crisis, but the existing case law already offers a "representative sample" to map the potential as well as the limits of climate change law and the contribution of the different parties involved, i.e., courts, political actors, civil society, climate scientists and legal scholars.

\section{References}

1. van Asselt, H., Kulovesi, K., Rajavuori, M., Savaresi, A.: Shell-shocked: a watershed moment for climate litigation against fossil fuel companies. Centre for Climate Change, Energy, and Environmental Law. Available at Shell-shocked: a watershed moment for climate litigation against fossil fuel companies, CCEEL (uef.fi)

2. Backes, C.W., van der Veen, G.A.: Urgenda: the final judgment of the Dutch Supreme Court. J. Eur. Environ. Plann. Law 17(3), 307-321 (2020)

3. van Berkel, D.: The Urgenda Climate Case against the Dutch Government, Urgenda (2020). Available at https://www.urgenda.nl/en/themas/climate-case/

4. Burgers, L.: Should judges make climate change law? Transnatl. Environ. Law 9(1) (2020). Symposium article. Available at Should Judges Make Climate Change Law? Transnational Environmental Law, Cambridge Core

5. Clark, P., Liston, G., Kalpouzos, I.: Climate change and the European Court of Human Rights: the Portuguese Youth Case. Blog of the European Journal of International Law (2020). Available at https://www.ejiltalk.org/climate-change-and-the-european-court-of-human-rights-the-portugueseyouth-case/

6. The Geneva Association, Climate Change Litigation - Insights into the evolving global landscape (2021). Available at Climate Change Litigation - Insights into the evolving global landscape. Research report, Geneva Association

7. Hartmann, J., Willers, Q.C.M.: Protecting Rights in Climate Change Litigation before European Courts (2021). Available at Protecting Rights in Climate Change Litigation before European Courts

8. Hösli, A.: 'Milieudefensie et al. v. Shell': a tipping point in climate change litigation against corporations? Climate Law 11, 195 (2021)

9. Khan, T.: Shell's historic loss in the Hague is a turning point in the fight against big oil, the Guardian, 1 June 2021. Available at: Shell's historic loss in the Hague is a turning point in the fight against big oil. Tessa Khan, the Guardian

10. Kobylarz, N.: The European Court of Human Rights: an underrated forum for environmental litigation. In: Tegner Anker, H., Egelund Olsen, B. (eds.) Sustainable Management of Natural Resources: Legal Instruments and Approaches (2018). Intersentia

\footnotetext{
${ }^{82}$ United Nations Environmental Programme [28], pp. 29-32.

${ }^{83}$ Burgers [4], p. 74.
} 
11. Kloepfer, M., Neugärtner, R.-D.: Liability for climate damages, sustainability and environmental justice. In: Kalh, W., Weller, M.-P. (eds.) Climate Change Litigation - A Hanbook. C.H. Beck Verlag, München (2021)

12. Krämer, L.: Climate change, human rights and access to justice. J. Eur. Environ. Plann. Law 16 (2019)

13. Lavrysen, L.: The French climate cases: legal basis and broader meaning. IUCN News (2021). Available at https://www.iucn.org/news/world-commission-environmental-law/202102/French-climatecases-legal-basis-and-broader-meaning

14. Luycks, J., Hendrikx, A.: CO2 emissions in international aviation cannot be mitigated as part of State aid to KLM. Clifford Chance 2020. Available at https://www.cliffordchance.com/insights/ resources/blogs/business-and-human-rights-insights/co-emissions-in-international-aviation-cannotbe-mitigated-as-part-of-state-aid-to-klm.html

15. Macchi, C., van Zeben, J.: Business and human rights implications of climate change litigation: Milieudefensie et al. v. Royal Dutch Shell, RECIEL (2021)

16. Meijer, B.: Dutch court sees no need to block state aid for airline KLM. Reuters (2020). Available at https://www.reuters.com/article/air-france-klm-netherlands-greenpeace-idINL1N2IP0NO

17. OECD, ESG Investing: Practices, Progress and Challenges, Paris, 2020. Available at ESG Investing: Practices, Progress and Challenges (oecd.org)

18. Pagano, M.: Overcoming Plaumann in EU Environmental Litigation an Analysis of ENGOS Legal Arguments in Actions for Annulment (2019). Diritto e Processo

19. Payandeh, M.: The role of courts in climate protection and the separation of powers. In: Kalh, W., Weller, M.-P. (eds.) Climate Change Litigation - A Hanbook. C.H. Beck Verlag, München (2021)

20. Peel, J., Osofsky, H.: A rights turn in climate change litigation? Transnatl. Environ. Law 7(1) (2018)

21. Savaresi, A., Auz, J.: Climate change litigation and human rights: pushing the boundaries. Clim. Law 9 (2019)

22. Setzer, J., Byrnes, R.: Global Trends in climate change litigation: 2020 snapshot, Grantham Research Institute on Climate Change, and the Environment. Available at Global trends in climate change litigation: 2020 snapshot-Grantham Research Institute on climate change and the environment (lse. ac.uk)

23. Setzer, J., Higham, C.: Global Trends in Climate Change Litigation: 2021 Snapshot, Grantham Research Institute on Climate Change and the Environment and Centre for Climate Change Economics and Policy. London School of Economics and Political Science, London (2021). Available at Globaltrends-in-climate-change-litigation_2021-snapshot.pdf (1se.ac.uk)

24. Sindico, F., Mbengue, M.M., McKenzie, K.: Climate change litigation and the individual: an overview. In: Sindico, F., Mbengue, M.M. (eds.) Comparative Climate Change Litigation: Beyond the Usual Suspects. IusComparatum-Global Studies in Comparative Law, vol. 47. Springer, Berlin (2021)

25. Stoddard, I., et al.: Three decades of Climate Mitigation: Why haven't we bent the Global Emissions Curve? Annual Review of Environment and Resources, June 2021. Available at Three Decades of Climate Mitigation: Why Haven't We Bent the Global Emissions Curve? Annual Review of Environment and Resources (annualreviews.org)

26. Tenwick, J.: NGOs win historic victory against French State for failing to tackle climate change. Oxfam International (2021). Available at https://www.oxfam.org/en/press-releases/ngos-win-historicvictory-against-french-state-failing-tackle-climate-change

27. Trexler, A.: Mediating climate change. Ecocriticism, science studies and the hungry tide. In: Gerrard (ed.) The Oxford Handbook of Ecocriticism. Oxford University Press, London (2014)

28. United Nations Environmental Programme, Global Climate Litigation Report: 2020 status review, Nairobi (2020). Available at Global Climate Litigation Report: 2020 Status Review, UNEP-UN Environment Programme

29. Voigt, C.: The first climate judgment before the Norwegian Supreme Court: aligning law with politics. J. Environ. Law 33(3) (2021)

30. Voigt, C.: The compliance and implementation mechanism of the Paris Agreement. RECIEL 25(2) (2016)

31. Weller, M.-P., Nasse, J.-M., Nasse, L.: Climate change litigation in Germany. In: Kalh, W., Weller, M.-P. (eds.) Climate Change Litigation - A Hanbook. C.H. Beck Verlag, München (2021)

Publisher's Note Springer Nature remains neutral with regard to jurisdictional claims in published maps and institutional affiliations. 